\title{
PEMANFAATAN SUMUR BOR PADA SISTEM PENYEDIAAN AIR BERSIH RSUD Dr. SAIFUL ANWAR MALANG \\ Rudy Sutijopramono ${ }^{1}$, Nur Haidah², Fitri Rokhmalia ${ }^{3}$ \\ ${ }^{1}$ RSUD Dr. Saiful Anwar Malang \\ 2,3 Jurusan Kesehatan Lingkungan Poltekkes Kemenkes Surabaya \\ Email : fitri.rokhmalia-13@fkm.unair.ac.id
}

\begin{abstract}
ABSTRAK
RSUD Dr. Saiful Anwar Malang menggunakan sumber air dari PDAM dan sumur. SAB yang bersumber pada sumur bor di IRNA I menyebabkan timbulnya pengendapan kotoran pada perpipaan. Penelitian ini bertujuan menggambarkan sistem penyediaan air bersih dari pemanfaatan sumur bor di IRNA I.

Metode penelitian ini bersifat deskritif. Objek, sasaran pada penelitian ini adalah sistem penyediaan dan kualitas air bersih dari pemanfaatan sumur bor di IRNA I,

Hasil penelitian pada perubahan tekanan aliran air bersih dari pola pengoperasian pompa rerata 8,78 jam/hari, 16 responden (80\%) dari 20 yang diwawancarai tentang kondisi air bersih di ruang pelayanan pernah mengetahui langsung terjadinya kekeruhan/endapan hitam yang keluar sesaat dari dalam kran, ke enam parameter fisik air yang diperiksa antara lain kekeruhan, warna, zat padat terlarut (TDS), suhu, rasa, dan bau memenuhi syarat untuk air bersih sesuai Permenkes RI No. 32 Tahun 2017, walupun angka hasil pemeriksaan TDS yaitu 1000 mg/l. Disimpulkan bahwa pemanfaatan sumur bor pada sistem penyediaan air bersih mengandung kadar kekeruhan dan zat padat terlarut tidak memenuhi syarat, penggunaan pompa yang tidak efektif menyebabkan terbentuknya pengendapan kotoran di dalam perpipaan.

Disarankan perlunya perbaikan sistem untuk menghilangkan pengendapan kotoran, penyaringan yang mampu mengurangi kandungan TDS dan kekeruhan.
\end{abstract}

Kata kunci: Sistem penyediaan air bersih, frekuensi perubahan tekanan, kekeruhan

\section{PENDAHULUAN}

Air memiliki peranan yang vital bagi kehidupan manusia sehari-hari. Proporsi air pada manusia diperkirakan mencapai $70 \%$ dari berat badannya. Manusia meng gunakan air bersih untuk air minum, memasak, mandi, mencuci, dan sebagainya. Air juga dapat menjadi media penularan penyakit yang baik. Begitu pentingnya air bersih sehingga harus dapat memberikan perlindungan kesehatan/keselamatan bagi manusia. Berkaitan dengan hal itu, penyediaan air bersih seharusnya memenuhi aspek kuantitas, kualitas dan kontinuitas.

RSUD Dr. Saiful Anwar telah menjadikan air tanah dengan sistem sumur bor sebagai kebutuhan utamanya. RSUD Dr. Saiful Anwar Malang menggunakan sumur bor berjumlah dua buah. Yaitu sumur bor di IPU dengan kedalaman \pm 115 meter dan di IRNA 1 dengan kedalaman \pm 50 meter. Kedua sumur bor tersebut yang penggunaannya $\pm 90 \%$ dari pemakaian keseluruhan. Sedangkan $\pm 10 \%$ nya menggunakan air bersih PDAM Malang 7 titik sambungan.

Pembersihan endapan di dalam perpipaan atau flushing dilakukan saat perbaikan/penggantian sarana perpipaan. Sedangkan kegiatan chlorinasi dilakukan di tiga tandon induk dua kali dalam seminggu. laboratorium internal maupun eksternal.Upaya penyehatan air bersih yang dilakukan adalah penyaringan, pengurasan tandon, flushing dan chlorinasi air bersih. Rata-rata pemakaian air bersih dari sumur bor IRNA I adalah 7.936 $\mathrm{m}^{3}$ /bulan. Sumur bor IPU sebanyak 26.355,936 $\mathrm{m}^{3} /$ bulan. Sistem penyaringan sebelum air masuk ke tandon induk menggunakan media batu zeolite, dan resin/karbon. Khusus di ruang Operasi, ruang Hemodialisa dan ruang Endoskopi menggunakan filter cartridge berukuran $5 \mu$. Kegiatan pengurasan tandon dilakukan dua kali setahun pada semua tandon. Pembersihan endapan di dalam perpipaan atau flushing dilakukan saat perbaikan/penggantian sarana perpipaan. Sedangkan kegiatan 
chlorinasi dilakukan di tiga tandon induk dua kali dalam seminggu.

Menonaktifkan pompa air berdampak pada fluktuasi aliran air di dalam pipa. Kecepatan aliran air yang terlalu kecil menyebabkan endapan di dalam pipa tidak dapat terdorong (Sepmita, 2017). Endapan hitam sering keluar sesaat di perpipaan air bersih yang bersumber pada sumur bor di IRNA Endapan tersebut keluar dari kran-kran yang dipastikan dari sumur bor di IRNA I. Kejadian timbulan endapan hitam yang dilaporkan biasanya berlangsung sesaat. Saat pengurasan, biasanya endapan hitam menempel di dinding dan lantai dasar tandon induk di IRNA I. Sedangkan tandon lain yang dipasok air langsung dari sumur bor di IPU tidak tampak endapan hitamnya. Pemeriksaan tentang kualitas air bersih di tandon IRNA 1 sebenarnya telah dilakukan rutin di laboratorium.

Permasalahan pada latar belakang tentang pemanfaatan sumur bor pada sistem penyediaan air bersih di RSUD Dr. Saiful Anwar Malang, menyebabkan timbulnya pengendapan kotoran pada perpipaan. Endapan tersebut terdorong ke kran di ruang pelayanan dan keluar menjadi air yang keruh/hitam untuk beberapa saat.

\section{METODE PENELITIAN}

Jenis penelitian pada proposal karya tulis ini adalah penelitian secara deskritif. Pada penelitian ini penulis ingin menggambarkan faktor yang memberikan petunjuk adanya gangguan kualitas fisik air bersih serta sistem penyediaan air bersih dari pemanfaatan sumur bor di IRNA I RSUD Dr. Saiful Anwar Malang.

\section{Variabel Penelitian}

a. Variabel bebas

1. Sistem Sistem penyediaan air bersih sumber pada sumur bor

2. Frekuensi perubahan tekanan aliran air bersih ke ruang pelayanan dari pola pengoperasian pompa air di tandon IRNA I.

3. Kualitas fisik air bersih dari pemanfaatan sumur bor

b. Variabel terikat

Kondisi air bersih di ruang pelayanan tentang kejadian kekeruhan.

\section{hASIL PENELITIAN}

Sistem penyediaan air bersih di RSUD Dr.Saiful Anwar Malang menjadikan sumur bor di IRNA I sebagaikebutuhan utama kedua setelah sumur bor di IPU yang rata-rata pemakaiannya $7.936 \mathrm{~m}^{3} /$ bulan. Dua sumur bor tersebut digunakan karena selain air bersih dari PDAM tidak mencukupi kebutuhan operasional rumah sakit sehari-harinya, juga biaya pemakaian yang cukup mahal. Air dari PDAM kemudian hanya digunakan untuk kebutuhan pelayanan di IPU (yang pasiennya VIP/VVIP), Instalasi.Hemodialisa serta Instalasi Farmasi.

Air dari kedua sumur bor digunakan untuk ruang pelayanan rawat jalan, rawat inap, instalasi- instalasi penunjang medik dan non medik, serta perkantoran. Air bersih dari kedua sumur bor diproses dulu ke dalam alat penyaring (wate treatment) sebelum dialirkan ke tandon induk (tandon IPU, tandon Instalasi Gizi, dan tandon IRNA I), lalu didistribusikan ke ruang pelayanan yang berbeda menggunakan mesin pompa air dari masing-masing tandon induk tersebut.

Berdasarkan Tabel. 1 diketahui setiap hari selama sebulan, pompa untuk mendistribusikan air bersih ke ruang pelayanan pernah mengalami tidak aktif dalam hitungan jam. Sebanyak 14 hari masing-masing terjadi $1 x$ dalam sehari frekwensi pompa air bersih tidak aktif, dan selama 16 hari frekwensinya $2 x$ dalam sehari.

Perhitungan persentase (\%) jumlah frekwensi pompa air tidak aktif baik 1x maupun 2x dalam sehari selama sebulan jika kualitas tidak aktifnya sama, adalah $\mathrm{y} / \mathrm{n} \times 100 \%$.

y : Jumlah frekuensi pompa air tidak aktif dalam sebulan

$\mathrm{n} \quad$ : Pengoperasian pompa dalam sebulan Persentase frekuensi pompa air tidak aktif dalam sebulan adalah: $30 / 30 \times 100 \%=\mathbf{1 0 0} \%$.

Sehingga setiap hari rata-rata pompa tidak aktif adalah $263,5 / 30=\mathbf{8 , 7 8}$ jam.

Berdasarkan Tabel 2. Hasil wawancara tersebut menjelaskan bahwa 16 responden dari 20 yang diwawancara pernah mengetahui langsung terjadinya kekeruhan/endapan hitam yang keluar sesaat dari dalam kran, dan hanya 4 responden $(100 \%)$ tidak pernah mengetahui adanya kekeruhan/ endapan hitam yang keluar sesaat dari dalam kran. Sebanyak 7 responden (35\%) yang pernah mengetahui langsung keluarnya air keruh/endapan hitam, dan 9 dari 20 responden (45\%) sering mengetahui langsung keluarnya air keruh/endapan hitam di kran ruangan. 
Tabel 1

Ceklist Pengoperasian Pompa Air Bersih di Tandon IRNA I.

\begin{tabular}{|c|c|c|c|c|c|c|}
\hline \multirow[b]{2}{*}{$\begin{array}{l}\text { Pemeriksaan } \\
\text { Ke }\end{array}$} & \multicolumn{2}{|c|}{$\begin{array}{l}\text { Durasi Pompa } \\
\text { Aktif (Jam) }\end{array}$} & \multicolumn{3}{|c|}{$\begin{array}{c}\text { Jeda Waktu Pompa Tidak Aktif } \\
\text { (Jam) }\end{array}$} & \multirow{2}{*}{$\begin{array}{l}\text { Jumlah } \\
\text { Frekwensi } \\
\text { Pompa } \\
\text { Tidak Aktif }\end{array}$} \\
\hline & $\underset{1}{\text { Pompa }}$ & $\underset{2}{\text { Pompa }}$ & $\begin{array}{c}\text { Pompa } 1 \\
\text { ke } \\
\text { pompa } 2\end{array}$ & $\begin{array}{c}\text { Pompa } 2 \\
\text { ke } \\
\text { pompa } 1\end{array}$ & $\begin{array}{c}\text { Lamanya } \\
\text { pompa } \\
\text { tidak } \\
\text { aktif }\end{array}$ & \\
\hline 01 & 6 jam & 10 jam & - & 8 jam & 8,0 & $1 x$ \\
\hline 02 & 4 jam & 10,5 jam & - & 9,5 jam & 9,5 & $1 x$ \\
\hline 03 & 5 jam & $\begin{array}{c}10,75 \\
\text { jam }\end{array}$ & 0,25 jam & 8 jam & 8,25 & $2 x$ \\
\hline 04 & 5 jam & 10,5 jam & 0,5 jam & 8 jam & 8,5 & $2 x$ \\
\hline 05 & 4 jam & 9,25 jam & 0,75 jam & 10 jam & 10,75 & $2 x$ \\
\hline 06 & 6 jam & 10 jam & - & 8 jam & 8,0 & $1 x$ \\
\hline 07 & 6 jam & 10 jam & - & 8 jam & 8,0 & $1 x$ \\
\hline 08 & 4 jam & 10,5 jam & - & 9,5 jam & 9,5 & $1 x$ \\
\hline 09 & 5,5 jam & 8,5 jam & 1 jam & 9 jam & 10,0 & $2 x$ \\
\hline 10 & 4,5 jam & 9 jam & 0,5 jam & 10 jam & 10,5 & $2 x$ \\
\hline 11 & 4 jam & 9,5 jam & 0,5 jam & 10 jam & 10,5 & $2 x$ \\
\hline 12 & 4 jam & 9,5 jam & 0,25 jam & 10,25 jam & 10,5 & $2 x$ \\
\hline 13 & 5 jam & 8,5 jam & - & 9,5 jam & 9,5 & $1 x$ \\
\hline 14 & 5 jam & 9 jam & - & 10 jam & 10,0 & $1 x$ \\
\hline 15 & 4,5 jam & 9,5 jam & 0,5 jam & 9,5 jam & 10,0 & $1 x$ \\
\hline 16 & 5 jam & 9 jam & 0,25 jam & 9,75 jam & 10,0 & $2 x$ \\
\hline 17 & 7,5 jam & 7 jam & - & 9,5 jam & 9,5 & $1 x$ \\
\hline 18 & 5 jam & 9,5 jam & 1 jam & 8,5 jam & 9,5 & $2 x$ \\
\hline 19 & 6 jam & 9 jam & 0,75 jam & 8,25 jam & 9,0 & $2 x$ \\
\hline 20 & 6 jam & 9 jam & - & 9 jam & 9,0 & $1 x$ \\
\hline 21 & 4 jam & 9,5 jam & - & 10,5 jam & 10,5 & $1 x$ \\
\hline 22 & 4 jam & 10,5 jam & 0,25 jam & 9,25 jam & 9,5 & $2 x$ \\
\hline 23 & 4 jam & 10 jam & 0,25 jam & 9,75 jam & 10,0 & $2 x$ \\
\hline 24 & 4 jam & 10 jam & 0,25 jam & 9,75 jam & 10,0 & $2 x$ \\
\hline 25 & 6 jam & 9,5 jam & 1,5 jam & 7 jam & 8,5 & $2 x$ \\
\hline 26 & 8 jam & 6,5 jam & 1,75 jam & 7,75 jam & 9,5 & $2 x$ \\
\hline 27 & 6 jam & 8 jam & 0,25 jam & 9,75 jam & 10,0 & $2 x$ \\
\hline 28 & 7 jam & 7,5 jam & - & 9,5 jam & 9,5 & $1 x$ \\
\hline 29 & 6 jam & 10 jam & - & 8 jam & 8,0 & $1 x$ \\
\hline \multirow[t]{2}{*}{30} & 6 jam & 9 jam & - & 9 jam & 9,0 & $1 x$ \\
\hline & & Jumlah & & & 263,5 & \\
\hline
\end{tabular}




\section{Tabel 2}

Rangkuman Hasil Wawancara di Ruang Pelayanan yang Air Bersihnya Terhubung Langsung dengan Sumur Bor di IRNA I

\begin{tabular}{cccc}
\hline No & Tema Wawancara & Responden & \% \\
\hline 1 & Tidak ada endapan hitam dari kran & 4 & 20 \\
\hline 2 & Pernah ada endapan hitam dari kran & 7 & 35 \\
\hline 3 & Sering ada endapan hitam dari kran & 9 & 45 \\
\hline & Jumlah & $\mathbf{2 0}$ & $\mathbf{1 0 0}$ \\
\hline
\end{tabular}

Tabel 3

Hasil Pemeriksaan Parameter Fisik Air Bersih di Ruang Pelayanan IRNA I Dari Sumur Bor

\begin{tabular}{|c|c|c|c|c|}
\hline No & Parameter & Satuan & $\begin{array}{l}\text { Baku Mutu } \\
\text { Air Bersih* }\end{array}$ & Hasil \\
\hline $\mathbf{A}$ & Sumur bor IRNA I & & & \\
\hline 1 & Kekeruhan & NTU & 25 & 0 \\
\hline 2 & Warna & TCU & 50 & 0,4 \\
\hline 3 & Zat Padat Terlarut (TDS) & $\mathrm{mg} / \mathrm{l}$ & 1000 & 442 \\
\hline 4 & Suhu & ${ }^{\circ} \mathrm{C}$ & $\begin{array}{c}\text { Suhu udara } \pm \\
3\end{array}$ & 28 \\
\hline 5 & Rasa & - & Tidak berasa & Tidak berasa \\
\hline 6 & Bau & - & Tidak berbau & Tidak berbau \\
\hline B & Kran Ruang 25 & & & \\
\hline 1 & Kekeruhan & NTU & 25 & 6 \\
\hline 2 & Warna & TCU & 50 & 1 \\
\hline 3 & Zat Padat Terlarut (TDS) & $\mathrm{mg} / \mathrm{l}$ & 1000 & 520 \\
\hline 4 & Suhu & ${ }^{\circ} \mathrm{C}$ & $\begin{array}{c}\text { Suhu udara } \pm \\
3\end{array}$ & 26 \\
\hline 5 & Rasa & - & Tidak berasa & Tidak berasa \\
\hline 6 & Bau & - & Tidak berbau & Tidak berbau \\
\hline C & Ruang Endoskopi ( flush & gg jaring & perpipaan ) & \\
\hline 1 & Kekeruhan & NTU & 25 & 17 \\
\hline 2 & Warna & TCU & 50 & 13 \\
\hline 3 & Zat Padat Terlarut (TDS) & $\mathrm{mg} / \mathrm{l}$ & 1000 & 492 \\
\hline 4 & Suhu & ${ }^{\circ} \mathrm{C}$ & $\begin{array}{c}\text { Suhu udara } \\
3\end{array}$ & 27 \\
\hline 5 & Rasa & - & Tidak berasa & Tidak berasa \\
\hline 6 & Bau & - & Tidak berbau & Tidak berbau \\
\hline
\end{tabular}

*Peraturan Menteri Kesehatan Republik Indonesia Nomor 32 Tahun 2017.

Berdasarkan Tabel. 3, diketahui bahwa :

a. Angka hasil pemeriksaan kekeruhan pada air bersih dengan cara flushing pada jaringan perpipaan terbaca 17 NTU, lebih tinggi dari sampel air yang keluar di kran Rung 25 yaitu 6 NTU, dan sampel sumur bor IRNA I terbaca 0 (nol).

b. Hasil pemeriksaan warna pada sampel air bersih di sumur bor IRNA I terbaca 0,4 TCU, sampel di kran Ruang 25 yaitu 1 , sedangkan dari kegiatan flushing jaringan perpipaan Ruang Endoskopi terbaca 13

c. Hasil pemeriksaan zat padat terlarut (TDS) pada sampel air bersih di sumur bor IRNA I terbaca $442 \mathrm{mg} / \mathrm{l}$, sampel kran Ruang 25 yaitu $520 \mathrm{mg} / \mathrm{l}$, dan sampel air saat flushing jaringan perpipaan Ruang Endoskopi terbaca 492 mg/l.

d. Hasil pemeriksaan suhu air di lokasi sampel sumur bor IRNA I terbaca $28^{\circ} \mathrm{C}$, suhu air di lokasi sampel kran Ruang 25 yaitu 26 
${ }^{\circ} \mathrm{C}$, serta suhu air saat flushing jaringan perpipaan Ruang Endoskopi terbaca 27 ${ }^{\circ} \mathrm{C}$.

e. Pemeriksaan rasa air dilakukan dengan indra perasa yaitu mencicipi langsung air tersebut dan didapatkan hasil pada masing-masing sampel

f. air tidak berasa.

g. Pemeriksaan bau pada masing-masing sampel ai $r$ bersih menggunakan indra penciuman yaitu dengan cara mencium bau air bersih, dan hasilnya tidak berbau. Kualitas fisik air bersih pada penelitian ini digambarkan dari hasil temuan terhadap variabel penelitian tentang frekuensi perubahan tekanan aliran air berdasarkan pola peng- operasian pompa di tandon IRNA.

h. Kondisi air bersih di ruang pelayanan berdasarkan hasil wawancara, dan hasil pemeriksaan parameter kekeruhan, warna, zat padat terlarut (TDS), suhu, rasa, dan bau, sesuai standar Permenkes RI No. 32 Tahun 2017.

\section{PEMBAHASAN}

\section{Pemanfaatan sumur bor.}

Permasalahan pemanfaatan sumur bor pada sistem penyediaan air bersih terlihat dengan adanya frekuensi perubahan tekanan aliran air bersih di dalam pipa rata-rata terjadi selama 8,78 jam/hari, yang berpotensi terjadinya pengendapan kotoran. Hal ini dipertegas juga dengan hasil wawancara bahwa $80 \%$ ruang pelayanan pernah mengalami kejadian timbulnya air keruh/endapan hitam yang keluar sesaat di perpipaan, serta hasil uji laboratorium terhadap parameter kekeruhan dan zat padat terlarut (TDS) yang cukup tinggi (hampir setengah dari kadar yang diperbolehkan menurut Permenkes RI No. 32 Tahun 2017). Walaupun keluarnya air keruh hanya sesaat namun secara estetika tidak cukup layak untuk dikonsumsi, kecuali untuk kebutuhan lain sehariharinya. Kekeruhan air (turbidity) bukan merupakan sifat dari air yang membahayakan, akan tetapi dapat menimbulkan dampak kekhawatiran karena dapat mengurangi estetika dan terkandungnya bahan-bahan kimia yang dapat memberikan efek toksik terhadap manusia (Sutrisno, 2002).

Permasalahan lain sistem penyediaan air bersih di RSUD Dr. Saiful Anwar Malang adalah sumur bor di IRNA I selama ini berkontribusi terhadap pemenuhan kuantitas dan kontinuitas air bersih yang rata-rata mencapai $31 \%$ dari kebutuhan air bersih RSUD Dr. Saiful Anwar Malang. Oleh karena itu keberadaan sumur bor di IRNA I tersebut tetap dipertahankan apalagi mampu menghemat anggaran operasional, mengingat biaya pemakaian dari PDAM yang cukup mahal.

\section{Frekuensi perubahan tekanan aliran air.}

Frekuensi perubahan tekanan aliran air diakibatkan karena pola pengoperasian pompa distribusi air bersih di tandon IRNA I yang ratarata terjadi selama 8,78 jam/hari. Penonaktifan berjam-jam pada pompa tersebut biasanya terjadi pada kondisi shift petugas jaga malam. Perlakuan pompa yang dinonaktifkan pada malam hari karena kebutuhan air bersih di ruang pelayanan sangat sedikit, sekaligus agar produksi air tanah bisa dihemat. Penonaktifan pompa pada siang hari/selama jam dinas pegawai dimungkinkan saat ada pergantian pompa lainnya secara manual. Pergantian biasanya memerlukan waktu antara $1 / 4$ jam sampai $13 / 4$ jam dari pompa 1 ke pompa 2 . Lama waktu tersebut biasanya karena proses persiapan dan pengecekan pompa yang akan menggantikan pompa lainnya.

Pompa tidak aktif berarti kecepatan aliran berkurang atau bahkan mengalami kehilangan tekanan air di dalam perpipaan, dan berpotensi terjadi pengendapan kotoran.

Proses pengendapan yang berulang setiap harinya selama berbulan-bulan ini bisa terjadi di sepanjang jaringan perpipaan air bersih dari mulai perpipaan di sumur bor sampai perpipaan di lokasi ruang pelayanan terjauh $\pm 325 \mathrm{~m}$.

Sebagian dari pengendapan yang terbentuk akan bergerak mengikuti aliran air menuju ujung perpipaan terdekat (kran) sesuai arah tekanan yang diberikan saat pompa distribusi dari tandon diaktifkan kembali. Keluarnya sebagian endapan yang terdorong menuju ujung perpipaan dapat terlihat ketika tiba-tiba air yang keluar dari kran menjadi keruh atau bahkan tampak hitam.

Endapan lain yang bertahan di dalam pipa primer berukuran $3 \varnothing$ dan sekunder berukuran $1 \varnothing-2 \varnothing$ bisa terjadi karena kondisi kekasaran permukaan bagian dalam pipa, mengingat pipa tersebut rata-rata berbahan besi. Endapan tersebut akan terdorong juga oleh sistem pendistribusian dari tekanan pompa atau bisa tertumpuk bersama timbulan endapan baru. Proses ini berpotensi akan berulang terus jika manajemen penyediaan air bersih dari sumur bor tidak di tata ulang. Endapan yang terlalu lama tertahan di dalam pipa juga dapat mengeras berupa kerak, yang berdampak pada 
pengurangan kecepatan aliran air bahkan

menyumbat perpipaan tersebut.

\section{Kondisi Fisik Air Bersih.}

Hasil wawancara terdapat 9 dari 20 orang responden ( $45 \%$ ruang pelayanan) mengaku air bersihnya sering keruh/ada endapan hitam sesaat dari kran dalam sebulan terakhir. Sedangkan 7 orang (35\% ruang pelayanan) mengetahui air bersihnya pernah keruh/ada endapan hitam sesaat dari kran.

Jika dijumlahkan ada $80 \%$ dari 20 ruang pelayanan yang penyediaan air bersihnya terhubung langsung pada sumur bor di IRNA I mengalami kejadian air keruh/endapan hitam sesaat. Sebagaimana diketahui bahwa syarat fisik air adalah jernih atau tidak keruh, tidak berwarna, tidak berasa, dan tidak berbau. Jika salah satu syarat tersebut tidak terpenuhi, air tersebut tidak sehat. Hasil wawancara membuktikan ada endapan kotoran sepanjang perpipaan akibat sistem penyediaan air bersih dan kualitas fisik air bersih yang tidak sehat dari pemanfaatan sumur bor di IRNA I RSUD Dr. Saiful Anwar Malang.

\section{Hasil pemeriksaan parameter fisik air bersih.}

1. Pemeriksaan parameter kekeruhan.

Pemeriksaan kekeruhan air bersih di laboratorium IPL RSUD Dr. Saiful Anwar Malang menggunakan alat Spectrofotometer UV VIS. Sampel air bersih dari hasil flushing di jaringan perpipaan Ruang Endoskopi mencapai yang tertinggi yaitu 17 NTU. Standar baku mutu untuk kekeruhan air bersih sesuai Permenkes RI No. 32 Tahun 2017 yaitu 25 NTU sehingga hasil di ketiga pemeriksaan tersebut memenuhi syarat sebagai air bersih.

Sebagai perbandingan dari hasil penelitian lain tentang kekeruhan air bersih oleh Andini (2017), adalah penelitian yang pernah dilakukan pada mata air di Solok, yaitu $<0,01$ NTU.

Hasil tersebut walaupun sama-sama memenuhi syarat tetapi secara estetika, air bersih dari sampel flushing di jaringan perpipaan cukup tinggi tingkat kekeruhannya.

2. Pemeriksaan parameter warna.

Pemeriksaan warna air bersih dilakukan dengan menggunakan alat Spectrofotometer UV VIS. Hasil pemeriksaan pada sampel air bersih yang cukup tinggi dari kegiatan flushing jaringan perpipaan Ruang Endoskopi terbaca 13 namun masih dibawah batas maksimal sesuai Permenkes RI No. 32 Tahun 2017, yaitu 50 TCU.

Warna yang terjadi bisa disebabkan adanya kontak antara bahan-bahan yang menimbulkan warna pada air tersebut, yang dihasilkan dari kontak antara air dengan reruntuhan organik seperti daun dan kayu yang semuanya dalam berbagai tingkat pembusukan. Bahan-bahan tersebut berisikan kentalan tumbuhantumbuhan dalam variasi besar antara lain tannin, asam humus dan bahan berasal dari humus dan bahan dekomposisi lignin, dianggap sebagai bahan yang memberi warna paling utama (Sutrisno, 2002). Warna air dari pemanfaatan sumur bor di IRNA I memenuhi syarat untuk standar air bersih.

3. Pemeriksaan parameter zat padat terlarut (TDS).

Hasil uji zat padat terlarut (TDS) di laboratorium IPL menggunakan alat Conductivity / Conductance. Hasil pemeriksaan parameter zat padat terlarut (TDS) pada sampel air sumur bor di IRNA I, kran Ruang 25, dan air hasil flushing jaringan perpipaan di Ruang Endoskopi, dianggap tinggi untuk ukuran sebuah institusi rumah sakit.

Tingkat zat padat terlarut (TDS) yang tinggi umumnya menunjukkan air sadah, dapat menyebabkan timbulnya kerak di dalam pipa, katup, saringan dan sistem pengolahan air "reverse osmosis" serta mengurangi kinerja dan menambah biaya perawatan sistem. Kandungan zat padat terlarut (TDS) yang cukup tinggi harus digunakan sebagai satu petunjuk estetika karakteristik air bersih dan menjadikan indikator yang harus diselidiki sebelum dikonsumsi (Sutrisno, 2002)

Standar total zat padat terlarut dalam air bersih yang diperbolehkan menurut Peraturan Menteri Kesehatan Republik Indonesia Nomor 32 Tahun 2017 yaitu $1000 \mathrm{mg} / \mathrm{l}$, sehingga air bersih yang bersumber pada sumur bor di IRNA I masih memenuhi syarat kesehatan sebagai air bersih.

4. Pemeriksaan parameter suhu.

Pemeriksaan suhu air bersih dilakukan saat pengambilan sampel di lokasi dengan menggunakan Thermometer. Tujuannya 
agar hasil pemeriksaan bisa dibandingkan langsung dengan suhu udara setempat, mengingat standar baku mutu air bersih menurut Permenkes RI No. 32 Tahun 2017 yaitu $\pm 3^{\circ} \mathrm{C}$ dari suhu udara sekitar. Suhu air bersih yang didapat dari hasil pemeriksaan sampel air sumur bor di IRNA I, kran Ruang 25, dan air hasil flushing perpipaan di R. Endoskopi lebih rendah dari suhu udara disekitar. Kondisi air bersih tersebut tidak akan mengakibatkan penyimpangan terhadap standar suhu, peningkatan toksisitas, kelarutan bahanbahan polutan, serta tidak dapat menimbulkan suhu bagi kehidupan mikroorganisme dan virus tertentu (Sutrisno, 2002).

Hasil pemeriksaan suhu air dari pemanfaatan sumur bor di IRNA I memenuhi syarat untuk standar air bersih sesuai Permenkes RI No. 32 Tahun 2017.

5. Pemeriksaan parameter rasa dan bau.

Pemeriksaan rasa air bersih dilakukan dengan indra perasa yaitu mencicipi langsung air tersebut dan didapatkan hasil pada masing-masing sampel air tidak berasa. Sedangkan pemeriksaan bau air bersih menggunakan indra penciuman yaitu dengan cara mencium bau air bersih, dan hasilnya tidak berbau. Hasil pemeriksaan pada air bersih yang terhubung langsung pada sumur bor di IRNA I tersebut tidak berasa dan berbau.

Bau dan rasa biasanya terjadi bersamaan dan disebabkan oleh adanya bahan-bahan organik yang membusuk, tipe - tipe tertentu organisme mikroskopik, serta persenyawaan-persenyawaan kimia seperti phenol(Sutrisno, 2002). Oleh karena hasil pemeriksaan yang tidak berasa dan berbau maka air bersih yang bersumber pada sumur bor di IRNA I tidak mengalami pembusukan organisme mikroskopik dan persenyawaan-persenyawaan kimia sebagaimana yang disebutkan dalam teori Sutrisno tersebut. Hasil pemeriksaan parameter rasa dan bau memenuhi syarat kesehatan untuk kebutuhan pemakaian air bersih sesuai Permenkes RI No. 32 Tahun 2017.

\section{KESIMPULAN}

Berdasarkan gambaran dan pembahasan di atas diperoleh kesimpulan sebagai berikut :

1. Sistem penyediaan air bersih yang bersumber pada sumur bor di IRNA I
RSUD Dr. Saiful Anwar Malang menyebabkan timbulnya pengendapan kotoran pada perpipaan secara terus menerus serta berulangnya kejadian aliran air keruh /endapan hitam keluar sesaat dari kran ruang pelayanan.

2. Pola pengoperasian pompa menimbulkan terjadinya frekuensi perubahan tekanan aliran air bersih setiap hari dan berakibat terbentuknya pengendapan kotoran di dalam pipa serta berperan dalam mendorong keluarnya air keruh/endapan hitam sesaat di ruang pelayanan.

3. Sebanyak $80 \%$ ruang pelayanan yang kondisi air bersihnya dari sumur bor di IRNA I, mengalami kejadian keluar air keruh/endapan hitam sesaat yang disebabkan oleh pengendapan kotoran di dalam perpipaan.

4. Hasil pemeriksaan parameter kekeruhan dan zat padat terlarut (TDS) terhadap air bersih yang bersumber pada sumur bor $\mathrm{di}$ IRNA I, memperjelas asal timbulnya pengendapan di dalam perpipaan serta keluar diujung perpipaan (kran) dalam kondisi keruh/endapan hitam.

5. Kualitas fisik air bersih dari pemanfaatan sumur bor IRNA I RSUD Dr.Saiful Anwar Malang, dipengaruhi Oleh jumlah angka kekeruhan dan zat padat terlarut (TDS). Kesimpulan secara keseluruhan dari penelitian ini, bahwa sumur bor di IRNA I mengandung jumlah angka kekeruhan dan zat padat terlarut (TDS) yang cukup tinggi, namun masih memenuhi syarat menurut Permenkes RI No. 32 Tahun 2017.

\section{SARAN}

1. Sistem penyediaan air bersih yang bersumber pada sumur bor di IRNA I RSUD Dr. Saiful Anwar Malang harus melalui filterisasi yang mampu menahan kandungan zat padat terlarut dan kekeruhan.

2. Pola pengoperasian pompa hanya digunakan untuk mendistribusikan air bersih dari sumur bor ke tandon penampung, untuk selanjutnya agar air dialirkan secara gravitasi ke ruang pelayanan.

3. Untuk menjamin kualitas fisik air bersih tetap memenuhi syarat kesehatan, harus dilakukan peng gantian pipa dari bahan besi ke bahan PVC yang permukaannya lebih halus dan aman bagi kesehatan. 
DAFTAR PUSTAKA

Sutrisno (2002), 'Tehnologi Penyediaan Air Bersih'. Penerbit PT Rineka Cipta, Jakarta.

Keputusan Menteri Kesehatan Republik Indonesia Nomor 1405 Tahun 2002 Lampiran 1 Tentang Persyaratan Kesehatan Lingkungan Kerja Perkantoran dan Industri.

Junaedi (2004), 'Pertumbuhan Bakteri Pada Ai Minum Dalam Kemasan Galon Isi Ulang Merk Zamin Pada Tingkat Konsumen Dengan Praktik Higiene Yang Berbeda Di kelurahan Tembalang Kota Semarang. Undip Press, Semarang.

Kementerian Lingkungan Hidup (2004), Pengendalian Pencemar an Air. Jakarta.

Warlina (2004), 'Pencemaran Air : Sumber Dampak Dan Penanggulangannya'. Institut Pertanian Bogor.id.scribd.com.

Rohimatu, A (2006), Perencanaan Sistem Plumbing Gedung Berlantai Tujuh.

Tunggul, P (2012), Studi Potret Pengelolaan Sumber Air di Desa Jawesari Kecamatan Limbangan Kabupaten Kendal.

Ranni (2012), Wawancara-Jendela I/mu.https://ranni. worldpress. com.

Kementerian PUPR Dirjen Cipta Karya, Buku 4 (2016), Panduan Pendampingan Sistem
Penyedia an Air Minum (SPAM)

PerpipaanBerbasis Masyarakat, 6-7.

Peraturan Menteri Kesehatan Republik Indonesia Nomor 32 Tahun 2017 Lampiran I Tentang Standar Baku Mutu Kesehatan Lingkungan Dan Persyaratan Kesehatan Air Untuk Keperluan Higiene Sanitasi, Kolam Renang, Solus Per Aqua, Dan Pemandian Umum.

Sepmita.A. (2017), Tinjauan Umum Sistem Distribusi Air Bersih'. Eprints. umm. ac.id $>$ jiptummpp. Unmuh, Malang.

Keputusan Direktur RSUD Dr. Saiful Anwar Malang Nomor 050 Tahun 2017 Tentang Review Kedua Rencana Strategi (Renstra) RSUD Dr. Saiful Anwar Malang Tahun 2014-2019.

Andini (2017), 'Uji Kualitas Fisik Air Bersih pada Sarana Ar Bersih Program Penyediaan Air Minum dan Sanitasi Berbasis Masyarakat (Pamsimas) Nagari Cupak Kabupaten Solok.

Wulandari (2018), 'Buku Ajar Kesehatan Lingkungan :Sanitasi Rumah Sakit'. Kementerian Kesehatan Rupublik Indonesia.

Peraturan Menteri Kesehatan Republik Indonesia Nomor 7 Tahun 2019 Lampiran I Tentang 'Kesehatan Lingkungan Rumah Sakit 